\title{
CURRENT TOPICS (1)
}

\author{
湿度七。光 \\ 山 本 達 夫 \\ 静岡大学電子工学研究所 $\mathbf{T} 432$ 浜松市城北 3-5-1 \\ (1984 年 3 月 2 日 受理)
}

\section{Humidity Sensors}

Tatsuo YAMAMOTO

Research Institute of Electronics, Shizuoka University

Johoku 3-5-1, Hamamatsu 432.

(Received March 2, 1984)

\begin{abstract}
The recent progress in cost and reliability of microprocessors and the interface circuits have brought more needs for every kind of reliable sensing devices. The requirements for controlling humidity as well as temperature in an ambient atmosphere have been extended to various fields such as industry, agriculture, housing and so on.

Definition and its standard are first given. Next, the present status of the art and the future trend in humidity sensors and also the related instruments are reviewd. Included are smart sensors or intelligent sensors composed of silicon micro-sensors and processing circuits, and electrolyte or ceramic sensors.

Finally, the relationships between solid surface and its moisture sensitive characteristics, that is, chemisorption and physisorption of water vapour on the solid surface are discussed.
\end{abstract}

\section{1.はじめに}

近年, マイクロプロセッサは処理速度, 信頼性の向上 と低価格化に伴なって，測定量を電気信号に変換するセ ンサに対するニーズが高まってきた。湿度センサについ て見れば, 生産現場におけるプロセス制御あるいは居住 空間の雾囲気調節は，従来その主たる対象は温度につい て行われてきたが，最近では，工業・農業そして住宅な ど多くの分野で湿度制御の重要性が認識されてきた。然 しながら，乙れ等の分野の要求を満足させる湿度センサ が少ないととも事実である。その理由は，湿度は温度と 較へて顕著に変わる物象が少なく，雾囲気中に含まれる 水分量す空気量に較べて著るしく少ないてと，また水蒸 気の材料表面に及ぼす過程が空気中の酸素そして徽量の 有害ガスとの相互作用を伴ない，その現象が物理化学的 に複雑であることむ起因している。本文では，主として 固体表面での水蒸気の物理吸着を応用した湿度センサの 現状と動向について述べる。

\section{2. 湿度について}

湿度とは，大気中に含まれる水蒸気の割合のととで， 気体中の水蒸気が飽和状態にどの位近いかを示すのに， 気体の水蒸気圧とその気体と同じ温度の飽和水蒸気圧と の比をパーセントで表わした量を相対湿度と呼び, $1 \mathrm{~m}^{3}$ の体積の気体の中に含まれる水蒸気の質量をグラムで表 わしたあのを絶対湿度と呼ぶ。また，露点は気体中の水 蒸気の分圧が飽和水蒸気圧に等しい温度で, 霜点は露点 が零度 $\left({ }^{\circ} \mathrm{C}\right)$ 以下の時の温度である。相対湿度は生体表面 の水分の蒸発量に比較的関連する量であるので, 一般に 用いられてきたが，一方温度と大気圧によって変化する 量である。従って，工業的には温度・圧力に無関係な絶 対湿度が好ましい。気体中の水蒸気含有率を規定する湿 度の弱点は, 質量の標準であるキログラム原器に相当す る可搬型の較正用原器が無いことである。最近になり， 湿度標準に関する問題が国内を含め国際的に取上げられ るようになり，我国では計量研究所において，精度の高 い恒湿発生装置とその湿度の絶対測定の方法を組合せた 
湿度標準器の 試作研究が行われている ${ }^{1)}$ 。国際法定計量 機関で作定された勧告草案に基づく湿度標準の流れ困は Fig. 1 亿示す通りである。水蒸気の質量とそれを含む気 体の体積または質量を測定する秤量法が最む精度が高く 湿度の絶対測定であり,てれを一次標準としている。2 次 標準は，2 点圧力法または 2 点温度法による恒湿発生装 置である。実用標準としては, 清浄な乾燥気体と水蒸気 飽和気体との混合法, 飽和塩による恒湿発生装置と基準 湿度センサとの組合せである。2 次標準に位置する基準 湿度計は, 通風乾湿球湿度計及び露点計である。前者は Assmann 氏の考案によるもので，木綿糸を巻きつけた 湿球は風速が常に $2.5 \mathrm{~m} / \mathrm{s}$ 以上の状態に保たれる。乾湿 球をサーミスターまたは白金抵抗体などで置換してブリ ッチ構成にすれば, 電気式湿度計となり湿度制御用電気 信号す取り出すととができる。1例として，マイクロ・ コンピュータを用いて多数の乾湿球センサ（超小型 IC 温度测定素子使用) を電気的に走查し, センサ出力を 演算処理して相対湿度 (RH) と温度を CRT 上に表示す る多チャンネル温湿度測定装置の試作報告むある ${ }^{2)}$ 。 湘定原理は 飽和水蒸気圧に対する温度の多項式および Sprung の水蒸気圧を求める近似式より相対湿度を算出 する。测定温湿度範囲 $-10 \sim+80^{\circ} \mathrm{C}$ 及び $10 \sim 100 \% \mathrm{RH}$ で誤差は $\pm 2 \%$ 以内で, 通風乾湿球湿度計と同程度の精 度が得られている。赤外線の吸収を応用する湿度計す多 くの研究者によって試みられている。強度 $I_{0}$ の光束が 光源より放射され, 水分を含む大気を通り減衰した後, 検知器に入る光束の強度を $I$ とすると

$$
I=I_{0} \exp (-\varepsilon C l)
$$

となる。乙こで， $\varepsilon は$ 吸収係数，Cおよびしをそれぞれ 水蒸気の濃度および光路長とすると， $\varepsilon$ およひ lがわか っていれば $I$ および $I_{0}$ を測定するととにより $C$ は決定

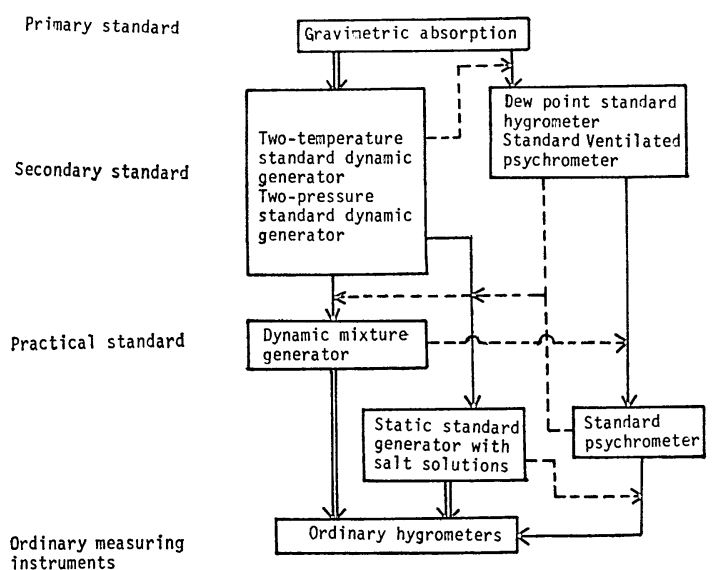

Fig. 1 Hierarchy scheme for instruments measuring humidity of gases.
できる。実際には，光束は回転するフィルターにより水 蒸気に吸収の無い波長 $\lambda_{0}$ と強く吸収される波長 $\lambda$ を選 び, 以後の光路には $\lambda_{0}$ と $\lambda$ を交互に通すようにする。と の方式は絶対湿度測定であり, 応答速度も 0.2 秒と早く 検知精度む $50 \mathrm{mg} / \mathrm{m}^{3}$ と高い ${ }^{3)}$ 。乙れ以外にマイクロ波 の吸収を利用した湿度測定装置も試作されているが4), いずれす装置が高価であるととが実用化の障害になって いる。

\section{3. 各種の湿度センサ}

Fig. 1の一般計器に相当する湿度センサないし湿度測 定機器は現在市販されているかまたは研究開発段階にあ るむのである。センサ自体に求められる一般的要求項目 としては, 小型・軽量・低価格そして信頼性が高いて と，測定レンジが広いとと，共存する他ガス成分に影響 されないととそして测定精度は $\pm 2 \sim 3 \% \mathrm{RH}$ 以内であ ること等である。以下に主として多孔体の内部を含めた 固体表面の物理吸着を応用した各種の湿度センサについ て紹介する。

\section{1 集積化ないし超小型センサ}

最近，集積回路技術の急速な進歩により，センサの超 小型化またはセンサと信号処理回路を一体化したいわゆ る Smart Sensor あるいは Intelligent Transducer と 呼ばれる分野が脚光を浴びてきた。一方，集積回路を含 む電子回路のパッケージの故障は, 密封されたケース 内に浸透した水分が大きく関与する。米国 Rome Air Development Centerでは, 質量分析器を用いて水分の 電子デバイスに与える影響を定量的に解析してきたが, この方法にはいくつかの制限と欠点のあるととが判っ だ)。すなわち, 電子デバイスの信頼性を確認するには, 相当数のサンプルを用意する必要のあるとと，パッケー ジに穴をあける破壊試験であるとと，さらに測定結果は 測定者の測定技術之分析機器の珄能に依存するとと等か らパッケージ内蔵型の超小型湿度センサが考えられた。 Fig. 2 (a) は半導体工業で Dew Point Sensor (露点 センサ）と呼ばれるむので，適当な絶縁基板上にくしの 歯形電極を取付けパッケージ内に組込まれる。ある温度 (露点または采点) で水蒸気が凝結し電極間導電率が増 大する。この表面効果を応用したセンサは冷却装置を必 要とし, また露点が零度以下の場合, 結果の解析に問題 があり定量的な測定には不向きであるとしている。

Fig. 2 (b) に示す $\mathrm{Al}_{2} \mathrm{O}_{3}$ センサは水分の物理吸着に 基づく体積効果を用いたすので,すでに過去 20 年以上生 物学, 薬学および食品工業等のプロセス制御に用いられ てきたものである。構造はアルミ基板表面を陽極酸化, アルミナ薄膜形成して上部に金電極を付けたコンデンサ 


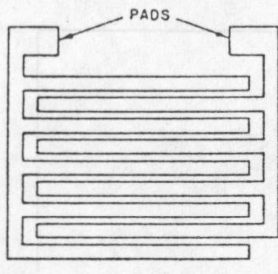

- DEw POINT* SENSOR (SURFACE EFFECT)

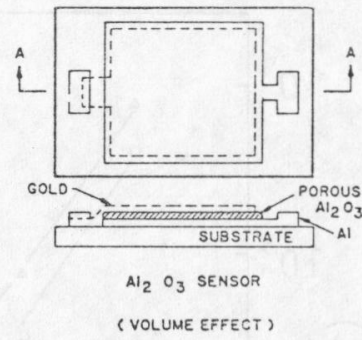

( VOLUME EFFECT)
Fig. 2 Two types of humidity sensors, (a) dew point sensor, (b) $\mathrm{Al}_{2} \mathrm{O}_{3}$ sensor.

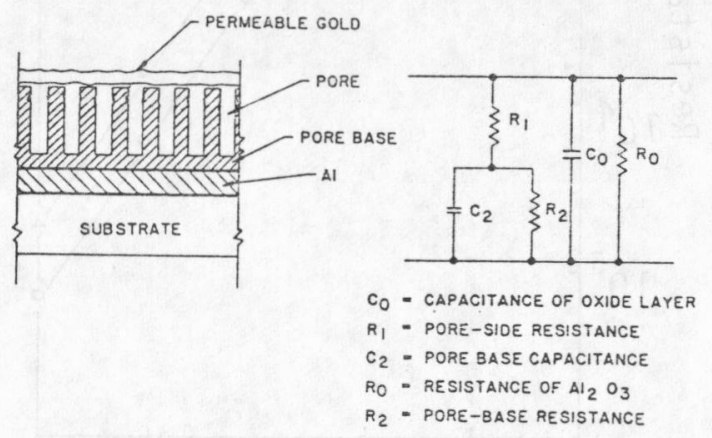

Fig. 3 (a) Cross-section and (b) equivalent circuit of $\mathrm{Al}_{2} \mathrm{O}_{3}$ sensor.

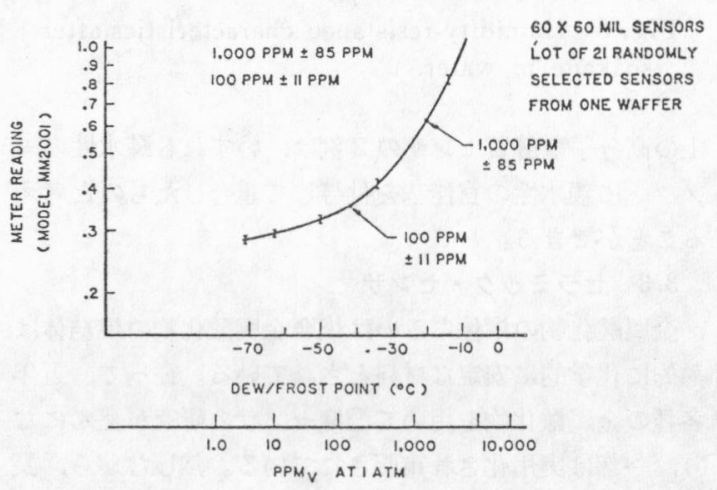

Fig. 4 Caribration curve for $152 \times 152 \mu \mathrm{m}$ $(60 \times 60$ mil $)$ device.

型である。Fig. 3（a)及び（b)はそれぞれセンサの断 面図と等価回路である。本素子の特性は Fig. 4 亿示す 通りで，縦軸の読みはセンサのアドミタンスに比例して いる。素子の大きさは約 $152 \mu \mathrm{m}$ 角で裏面はハンダ付け またはエポキシ樹脂にマウントできるようにクロムと金 が蒸着されている。1枚のウエハからランダムに選ばれ た 21 個の素子で $100 \mathrm{ppm}$ の水分量で $11 \%, 1000 \mathrm{ppm}$ で $8.5 \%$ 以内のバラッキである。

Fig. 2(a)に示した結露センサに関連して, オランダ
の Delft 工科大学で試作された集積化センサの例を述べ

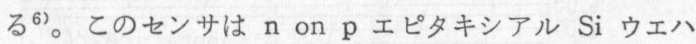
上に温度及び露点センサを一緒に形成したすので, n I ピタキシアル層上に厚さ $1 \mu \mathrm{m} の \mathrm{SiO}_{2}$ 膜を形成し，乙 の上にアルミくしの歯電極（電極幅，間隔ともに10 $\mu \mathrm{m}$ ) を蒸着する。温度センサは露点センサの近傍に形成する $\mathrm{p}$ - $\mathrm{n}$ 接合ダイオードの順方向電圧の温度依存性を用い る。とのセンサは電子泠却装置と一体化して用いるむの で, 結露による電極間容量の急激な増大時の温度を測定 する方式である。Fig. 2(b) のアルミナ・センサの変形 として Si-MOS ダイオードの絶縁層を $\mathrm{SiO}_{2}$ と $\mathrm{Al}_{2} \mathrm{O}_{3}$ 膜の二重層にする容量型センサの報告もある7)。また, このダイオードを MIS-FET のゲート部分に使用すれ ば，湿度の変化に応じてチャネルコンダクタンスが変る 湿度センサへの応用む可能となる。との種の新しい感湿 素子としては，MIT で開発された CFT (Charge Flow Transistor) がある8)。これは Enhancement 形nチャ ンネル MOS トランジスタのゲート部分を Fig. 5 に 示すように, ゲート電極の中央部を感湿性のポリマーで 覆う。ゲート電極に正極性パルスを印加すると，正電荷 は一定時間後ポリマー上に一様に分布し同時に $\mathrm{n}$ チャネ ルがゲート絶縁膜下に形成されドレン電流が流れ始め る。この遅れ時間が周りの相対湿度で変化することを応 用したものである。また，吸着した水分は還元性ガスと 同様に表面ドナーとして働く。水の吸着により, $\mathrm{n}$ 形半 導体は導電率を増し, $\mathrm{p}$ 形半導体は減少する。半導体薄 膜の厚さがデバイ長と同程度またはそれ以下では，吸着 によるゲート作用が期待できる。この効果を利用したト ランジスタは AET (Absorption Effect Transistor)と 呼ばれ， $\mathrm{p}$ 形半導性をむつ窒化バナジウムを用いたトラ ンジスタが報告されている ${ }^{9)}$ 。上，超小型センサない し集積化を目ざしたセンサの開発動向について述べた。 集積回路自体は水蒸気に対して極めて弱いものであり， 一方湿度センサは検出部分を雲囲気に暴露して使用する むのである。特に薄膜表面を用いる素子は，表面のガス 污染その他の吸着に敏感に反応する。従って, 現状では 清浄で低湿な雾囲気での使用のみに制限されよう。

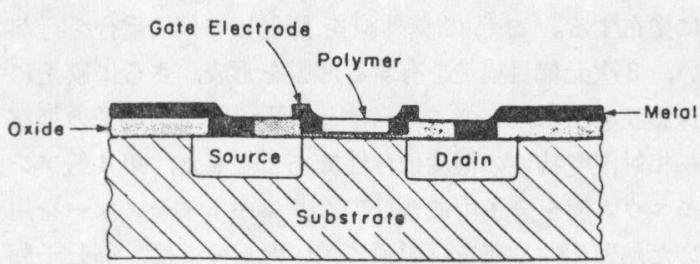

Fig. 5 Cross-sectional view of Charge Flow Transistor (CFT). 


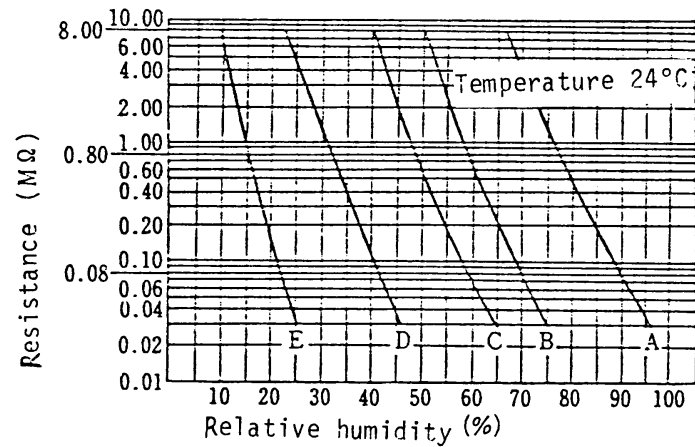

Fig. 6 Humidity-resistance characteristics of Dunmore type sensor.

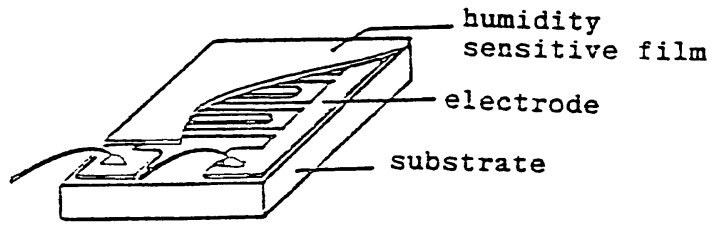

Fig. 7 Typical structure of thin film sensor composed of cross-linked polystyrene sulfonate.

\section{2 電解質センサ}

電解質を用いるセンサは，メタ燐酸カリ・五酸化燐膜 など色々の電解質で試みられてきたが，代表的なむの は, Dunmoreによって開発された Licl 電気抵抗式セン

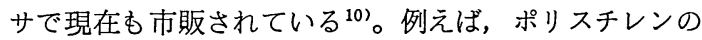
ボビンに白金線やパラジュウム線 2 本を平行スパイラル に巻き，その表面に部分けん化したポリビニール・アセ テートと塩化リチウムの混合水溶液を㓌布するむので, Fig. 6 はその電気抵抗の相対湿度特性である。図中, 曲線 $\mathrm{A}$ はポリビニール・アセテートのみの特性で，以上 曲線 $\mathrm{B} ， \mathrm{C} ， \mathrm{D}$ 及び $\mathrm{E}$ は塩化リチゥムの添加量をそれぞ れ $0.25,0.5,1.0$ 及び $2.2 \%$ 之增加したものの特性で ある。最近，高分子電解質膜を用いたセンサが開発さ れ，耐熱性・耐湿性及び耐薬品性にすぐれたすのが市販 されるようになってきた。Fig. 7 亿示す構造のセンサ はその 1 例である。アルミナ基板上にスクリーン印刷に より一対のくしの歯形金電極を形成し，感湿材料である スチレンスルホン酸塩に架橋剤を添加した溶液を基板上 に釷布する。乙れに紫外線を照射して架橋重合を行な い， 3 次元網目構造を有する薄膜を形成，さらに膜上に 保護膜を積ねたものである ${ }^{11)}$ 。Fig. 8 は本素子の抵抗 一相対湿度特性の温度依存性である。また，第 4 級アン モニウム塩を分子中に含むアクリレート・モノマーを用 いた熱硬化性樹脂を感湿膜に用いたものでは，高分子膜 中に存在する $\mathrm{N}^{+}\left(\mathrm{CH}_{3}\right)_{3} \mathrm{Cl}^{-}$が水分により解離して, $\mathrm{Cl}^{-}$イオンがイオン伝導性に寄与するとしている ${ }^{12)}$ 。以

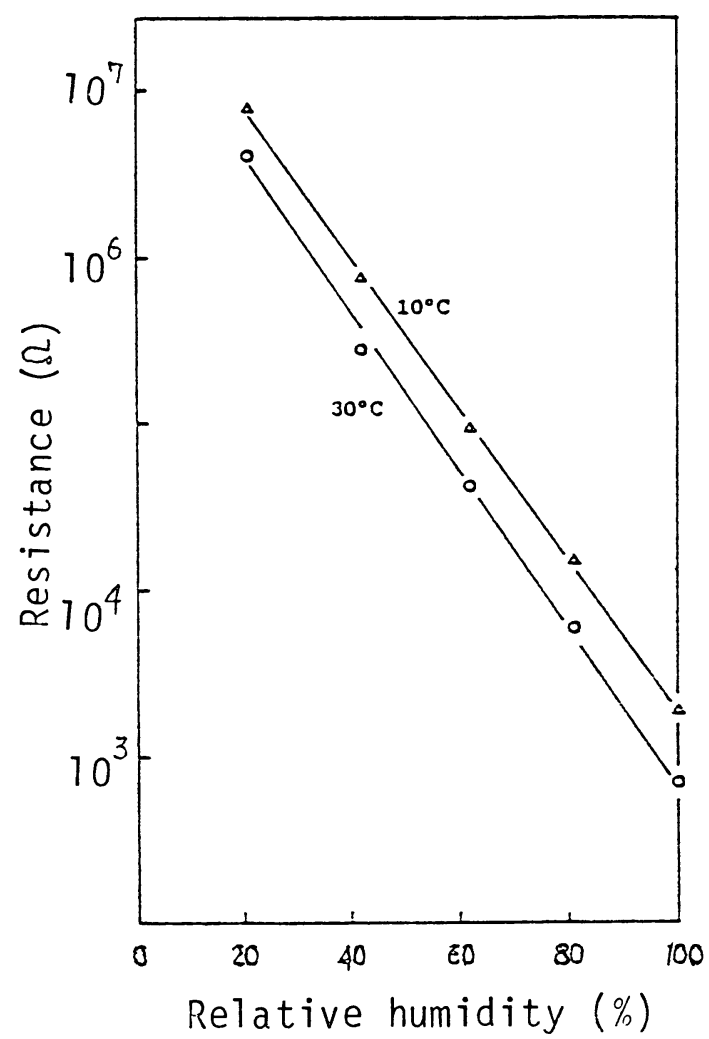

Fig. 8 Humidity-resistance characteristics after soakage in water.

上の高分子電解質センサの 2 例は，いずれむ疎水性のモ ノマーに親水性の官能基を付与して重合したものと考え るととができる。

\section{3 セラミック・センサ}

金属酸化物の単体あるいは複合金属酸化物の焼結体は 熱的に化学的に安定な材料とされている。従って，近年 各種の金属酸化物を用いて湿度センサの研究が盛んにな り，一部は実用化され市販されている。然しながら，長 期間浪る安定度を問題にする場合満足すべき段階に達 したとは考えられない。

金属酸化物を用いたセラミックスの清浄表面は，大気 中の水分が解離吸着して金属イオンと結合して表面水酸 基を形成する。乙の表面水酸基が時間ととすに増大する か，或は他ガスの化学吸着または他物質の付着污染なご により除々に感湿特性が劣化する。この欠点を除去する 手段として，セラミックス表面を定期的にヒーターによ り加熱クリニングする方法が開発された ${ }^{13)}$ 。Fig. 9 に 示す構造のセンサは， $\mathrm{Al}_{2} \mathrm{O}_{3}$ を主体とした多孔質焼結体 をべースにしてその両面に $\mathrm{RuO}_{2}$ 電極を付したむのであ る。多孔質を通じて雾囲気の水蒸気量に応じた水分子が 

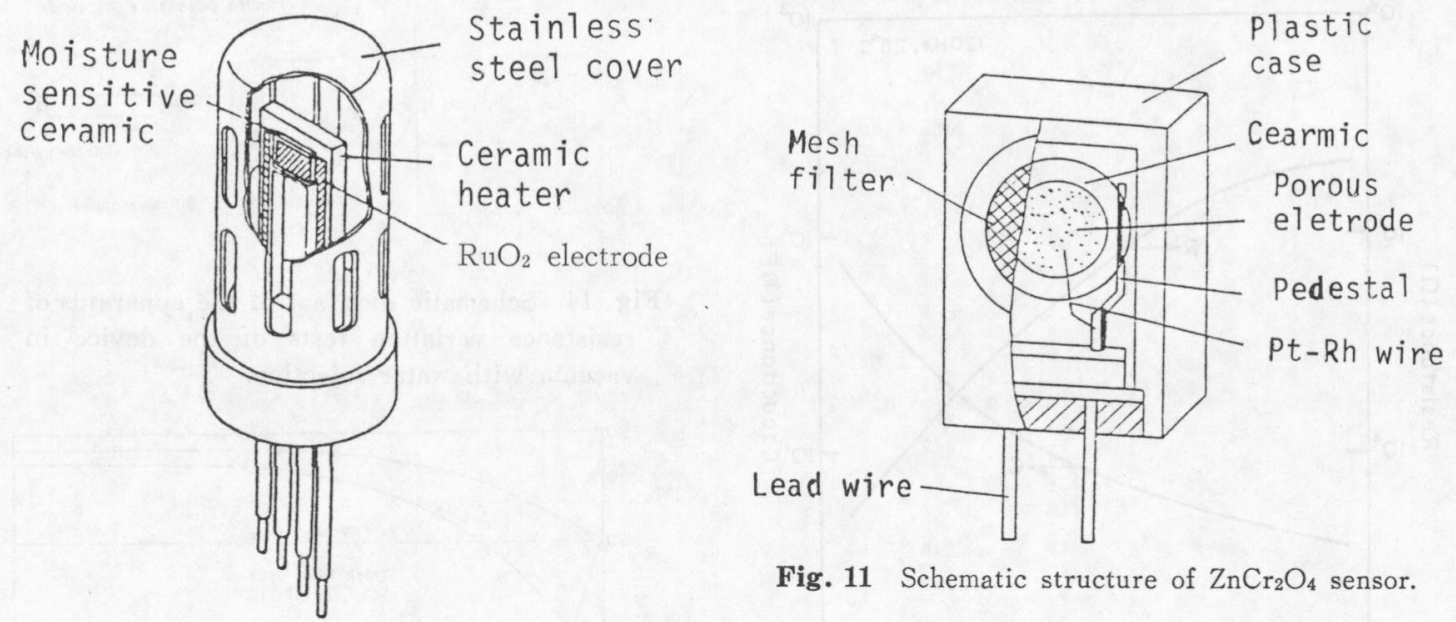

Fig. 9 Schematic structure of $\mathrm{Al}_{2} \mathrm{O}_{3}$ sensor with ceramic heater.

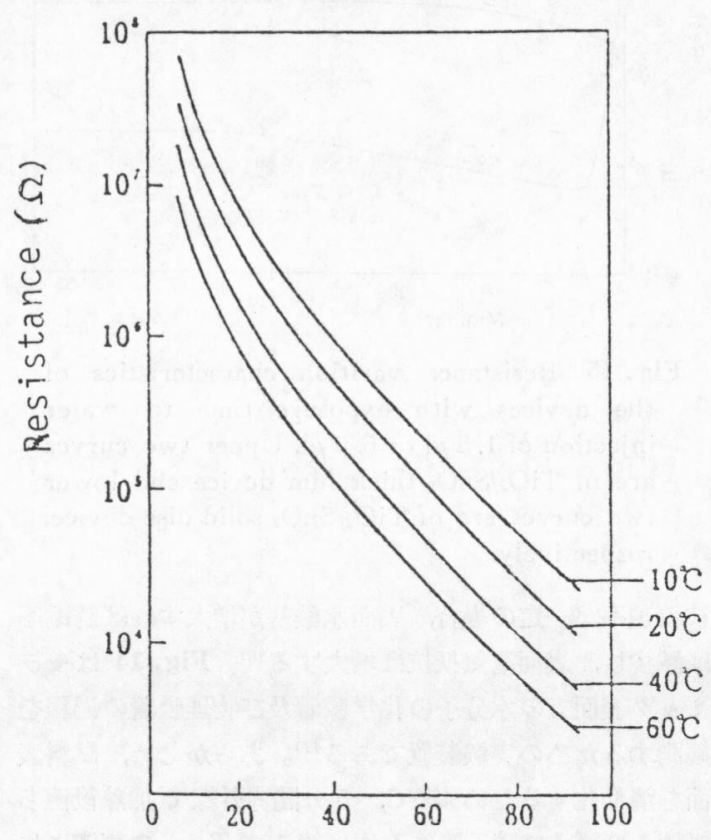

Fig. 11 Schematic structure of $\mathrm{ZnCr}_{2} \mathrm{O}_{4}$ sensor.

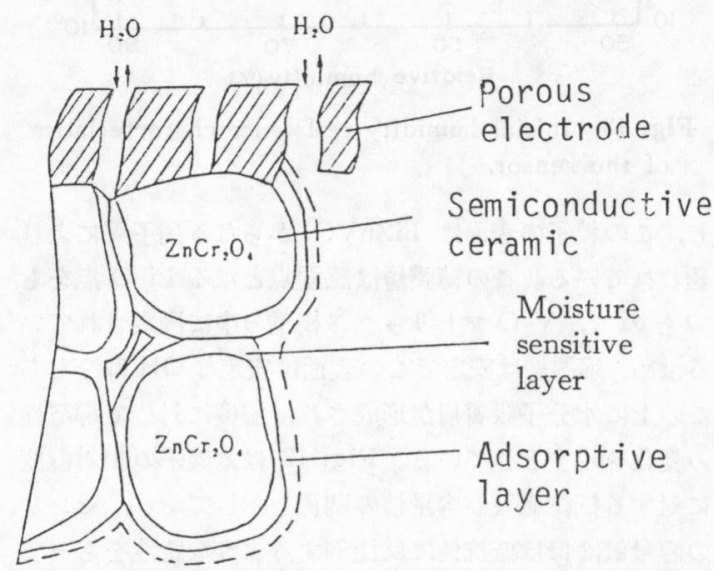

Fig. 12 Cross-sectional view of humidity sensitive $\mathrm{ZnCr}_{2} \mathrm{O}_{4}$ ceramics.

依存性は普通電子回路と温度検出素子の組合せで補償さ れる。

加熱型センサは，センサ表面の污染を加熱によって除 去できるので，耐環境性において特にすぐれた性能を有 する反面, 加熱用電源・ヒーターを必要とし, 電力消費 量む大きくなる。また，使用環境条件によっては加熱型 素子の利用が好ましくない場合も少なくないので，高分 子センサととむにセラミック・センサの研究開発の分野 でも非加熱型への指向が高まってきた。

Fig. 11に示す構造は非加熱型センサの一例である ${ }^{14)}$ 。

微粒子表面に物理的な吸脱着をするととにより，バルク 表面の電気抵抗が指数的に変化するととを応用したすの である。近傍に配置したセラミック・ヒーターにより一 定周期で自動的に加熱クリニング (500 C, 1 分間) する ように設定され，测定誤差は $\pm 4 \% \mathrm{RH}$ となっている。

Fig. 10 はその感湿特性の温度依存性を示し, この温度 感湿体は $\mathrm{ZnO}, \mathrm{Cr}_{2} \mathrm{O}_{3}, \mathrm{Li}_{2} \mathrm{CO}_{3}$ 及び $\mathrm{V}_{2} \mathrm{O}_{5}$ の混合粉体 を $800^{\circ} \mathrm{C}$ で婮焼, 粉砕後ディスク状にプレス, $1300^{\circ} \mathrm{C}$ で 焼成， $0.2 \mathrm{~mm}$ 厚にラップ後画面に金電極を付したむの である。Fig. 12 に示すセラミック素体の断面構造のよ うに, ベースのセラミックスとして $\mathrm{ZnCr}_{2} \mathrm{O}_{4}$ の $2 \sim 3 \mu \mathrm{m}$ 粒子からなる多孔質のスピネル構造の結晶粒子からな 


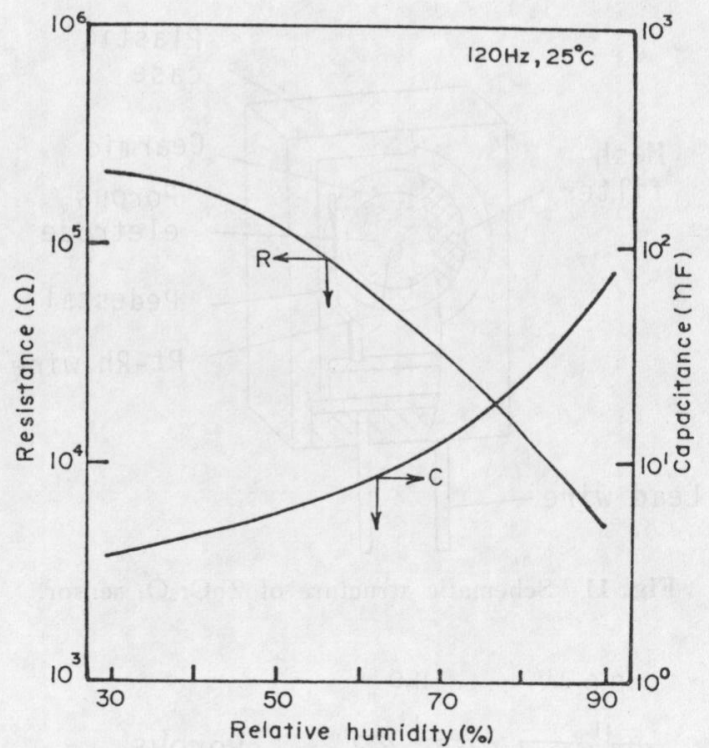

Fig. 13 Initial humidity-resistance characteristics of the sensor.

り，この粒子の表面は $\mathrm{LiZnVO}_{4}$ からなる硝子層により 覆われている。との薄膜層は感湿点となる $\mathrm{Li}-\mathrm{O}$ 点をむ つあので，V-O マトリックス構造の中に固定されてい るため, 感湿層は安定でこの表面は安定な $\mathrm{OH}$ 基をあち この上に水分子吸着層が形成され，湿度に対して導電性 の変化を示すとしている。Fig. 13 は本素子の相対湿度 に対する抵抗値及び容量值の関係を示しており，センサ の容量值はほぼ低抗值に反比例するような特性をむって いる。

\section{4. 固体表面之感湿特性}

金属酸化物の多孔性焼結体あるいは親水性の官能基を 含む高分子は水分の吸脱着を容易にする。多孔体では, 水蒸気の吸着は相対湿度の増加ととむに単分子層加ら多 分子層を形成し毛細管凝縮する。そして，その細孔半径 が小さい程低湿度域で水が凝縮する。完全に脱水した酸 化物表面では, $\mathrm{H}_{2} \mathrm{O}$ が解離して $\mathrm{H}^{+}$と $\mathrm{OH}^{-}$になり, $\mathrm{OH}^{-}$は金属イオン上に, $\mathrm{H}^{+}$は酸素イオン上に化学結合 し，それぞれ表面水酸基を形成する化学吸着が起とる。 J. H. Anderson 等はシリカ・ゲルを用いて吸着水に よる電気伝導度の変化と実験と理論による解明を試み

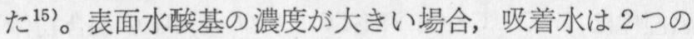
水酸基を水素結合し，濃度が小さい場合は 1 つの水酸基 とのみ結合する。 2 つの水酸基と結合した水分子は後者 之較ぺて, 電場内での配向が難しい。すなわち，1つの 水酸基のみに水分子が吸着するような条件下のほうがプ ロトンによる電気伝導性が良くなる。吸着水による表面

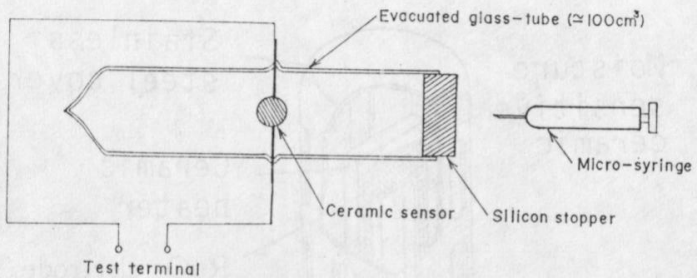

Fig. 14 Schematic diagram of the apparatus of resistance variation tests of the device in vacuum with water injection.

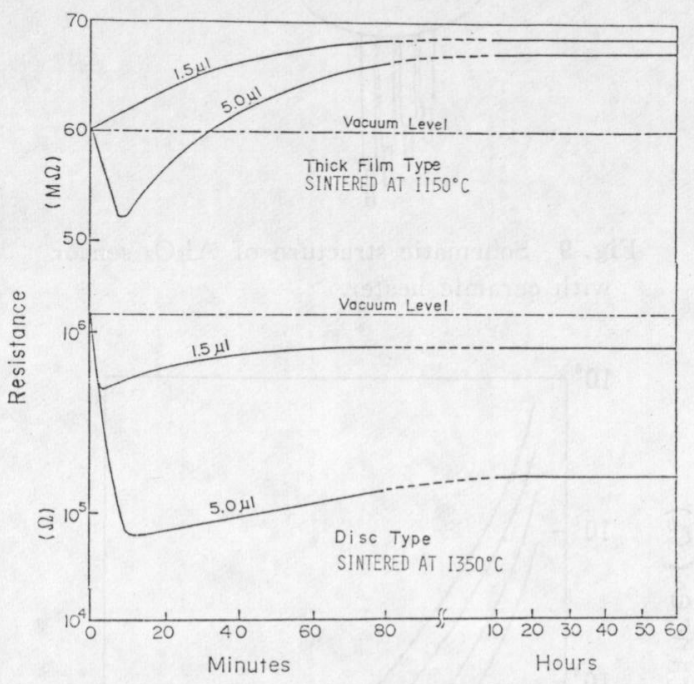

Fig. 15 Resistance varition characteristics of the devices with exposure time to water injection of $1.5 \mu 1$ or $5.0 \mu 1$. Upper two curves are of $\mathrm{TiO}_{2} / \mathrm{SnO}_{2}$ thick film device and lower two curves are of $\mathrm{TiO}_{2} / \mathrm{SnO}_{2}$ solid disc device, respectively.

被覆覆率が一定の場合，表面水酸基が増大すれば誘電率 は減少し，表面電気抵抗は増大する ${ }^{16)}$ 。Fig. 14 はセう ミック表面での水分子の化学吸着及び物理吸着の過程を 観測するための実験装置である ${ }^{17) 。 あ ら か し ゙ め, ~}$ 面を清浄化するため $450^{\circ} \mathrm{C}$ ，5分間赤外線で 加熱後直ち に約 $100 \mathrm{~cm}^{3}$ の硝子管に入れ，約 $10^{-5}$ Torr の真空にし て封じ切る。他端のシリコンゴム栓を通してマイクロシ リンジにより真空中に純水を規定量注入して素子の電気 抵抗の計測を開始する。Fig. 15 はその経時特性の 1 例

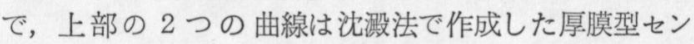
サ18)，下の 2 つの曲線はディスク型素子の特性である。 いずれの素子も $\mathrm{TiO}_{2}$ と $\mathrm{SnO}_{2}$ を主体にした焼結体で ある。

この場合, 電気抵抗の経時変化に厚膜型とディスク型 で大きな相違が見られる。すなわち，厚膜型では水分が 導入されても飽和時の抵抗は真空レベル以下にはならな 
い。乙の原因の一つは，焼成温度の違いによるあので， 焼成温度の高いディスク型では粒成長が進み，粒子間を 結合するネック部の断面積が大きいため水分の化学吸着 による電子空乏層のひろがりによる電気抵抗の增大が余 りないためである。また，電気抵抗の水分導入時の急速 な低下は勿論水のプロトン電導の增加によるものである が，抵抗値は一定時間後再び上昇反転する。乙れは，水 分の解離吸着による水酸基の表面被㠅率の経時変化とプ ロント電導による表面電気抵抗の変化の競合関係によっ て決まるむので, ての機構は複雑であり，解明できる段 階にはない。

また, 多孔体表面は油・歴挨等による目づまり等の污 染以外に, 大気中の $\mathrm{CO}, \mathrm{NO} x$ 及び $\mathrm{SO}_{x}$ 等の化学吸 着による表面伝導度の変化むあるので, 特に非加熱型也 ンサの場合信頼性に大きな影響がある。

\section{5. むすび}

一般計器に対応する小型・軽量・安価で信頼性の高い 湿度センサの出現が望まれているが，現状では長期に渡 って $\pm 2 \%$ RH 以内の測定精度を保証するセンサないし 測定機器は極めて少ないように思われる。なお，紙数の 関係で，私見によって選んだ少数のセンサの紹介に止ど まったととをお詑びするととむに，日頃有益な御助言を 賜っている本学工学部合成化学科小林純一教授に深謝す る。
文献

1) 稲松照子: 電子通信学会技術研究報告 82 (1982) 25.

2) 南任靖雄 : 電子通信学会論文誌 J-65-C (1982) 17.

3) 木村茂行, 市村 勉 : 計測技術 701 (1970) 日本工 業出版.

4) 三浦太郎, 山本隆洋 : 電気学会研究資料 EDD-79 (1979) 83.

5) M. G. Kovac et al: Solid State Technology (Fed, 1978) 35.

6) 例えば, NIKKEI ELECTRONICS (Oct. 1981) 142.

7）稲垣慎太郎外 : 第 1 回「センサの基礎と応用」シ ンポジウム講演予稿集 (1981) 83.

8) S.D. Senturia et al: Appl. phys. Letters 30 (1977) 106.

9) 光藤裕之 : セラミックス 15 (1980) 339.

10) F. W. Dunmore: J. Res. NBS 23 (1939) 701.

11）杉原孝志，実吉秀治：センサ技術 3 (1983) 41 .

12) 坂東勝正, 前橋康治 : センサ技術 3 (1983) 50 .

13) 新田恒治他: National Technical Report 24 (1978) 422.

14) S. Uno et al : proceeding of the 2 nd Sensor Sgmposium (1982) 85.

15) J.H. Anderson et al: J. phys, Chem. 72 (1968) 3662.

16）清山哲郎他 : 化学センサ, 講談社サイエンティフ イク, 93.

17) T. Yamamoto et al : IEEE Trans. on CHMT, CHMT-5 (1982) 238.

18）山本達夫，清水洋美 : 電子通信学会論文誌 J64-C (1981) 9. 